\title{
Bibliometric Study and Methodological Quality Indicators of the Journal Porta Linguarum During Six-Year Period 2008-2013
}

\author{
Clemente Rodríguez Sabiote \\ José Álvarez Rodríguez \\ Universidad de Granada
}

Received: 22 April 2014 / Accepted: 4 March 2015

ISBN: $1697-7467$

\begin{abstract}
In this study we have developed a bibliometric study in the journal Porta Linguarum about the methodological quality indicators of the empirical articles published during the sexennial period 2008-2013. The results obtained show that, it was a journal in which quantitative papers predominate along with theoretical works. The results also suggest that, this journal should improve some fundamental methodological issues, related mainly to the types of samples, novelty of the literature and validity and reliability of the data collection instruments. On the contrary, it has achieved excellent results in the indicators related to the internationality of authorship and references managed, language processing, and control of inbreeding for authorship.
\end{abstract}

Keywords: Bibliometric analysis. Methodological quality indicators.

Estudio bibliométrico e indicadores de calidad metodológicos de la revista Porta Linguarum durante el sexenio 2008-2013

RESUMEN. En el presente trabajo hemos desarrollado un estudio bibliométrico de la revista Porta Linguarum sobre indicadores de calidad metodológicos de los artículos de naturaleza empírica publicados durante el sexenio 2008-2013. Los resultados logrados revelan que se trata de una revista donde predominan los trabajos de corte cuantitativo, junto a otros de carácter más teórico. Los datos obtenidos, también apuntan a que la revista citada debe mejorar algunos aspectos metodológicos esenciales, relacionados, sobre todo, con la tipología de muestreos, novedad de las referencias bibliográficas y criterios de calidad de los instrumentos de medida. Por el contrario, ha logrado excelentes resultados en los indicadores sobre internacionalidad de las autorías y las referencias bibliográficas manejadas, idioma de elaboración, así como en el control de la endogamia por autoría.

Palabras clave: Análisis bibliométrico. Indicadores de calidad metodológica.

\section{InTRODUCTION}

Bibliometric studies have experienced a wide growth over the last few years, definitely, due to the growing concern about the quality of scientific journals. These studies focus their attention in the study and analysis of the scientific activity calculating the so called bibliometric indicators, for example: production, circulation and dispersion. Some of the 
most recent contributions on this topic in the fields of Education and Psychology at national level are those of Carpallo-Bautista and Burgos-Bordonau (2008); Goñi (2009); Buela-Casal, Bermúdez, Quevedo-Blasco and Castro (2010); Quevedo-Blasco, Díaz-Piedra and Guglielmi (2010), Delgado López-Cózar, Ruiz-Pérez and Jímenez-Contreras (2010), Buela-Casal and Zych (2010); Buela (2010); Zych (2011); Mintegi, Esnaola, Díaz and Goñi (2011); Gómez-García, Ramiro, Ariza yand Granados (2012); Giménez Toledo (2014); Níkleva and Cortina (2014); Flórez Parra, López Pérez and López Hernández (2014) and Olivas Ávila and Lechuga (2014).

However, in all these studies the calculation of indicators has been poorly linked to those indicators we have named -quality bibliometric studies-. These indicators focus their attention, precisely, in those methodological aspects to what Arnau, Anguera and Gómez (1990) call technical-methodological and statistic-analytical levels of empiric research reports, thus, moving away from impact factors related to visibility and citation.

Regarding the history of the journal evaluated itself, we must point out, first that the journal launched its first number in 2004. As professor Madrid (2004) says in the introduction of its first number- this journal Porta Linguarum was born with an interdepartamental, interuniversity and international vocation whose objective of study and research was the foreign languages didactics. The magazine aims to inform and disseminate those investigations related to this area of knowledge, empirical studies, critical reviews, as well as the presentation of theoretical models, along with educational proposals that are related to this subject, spreading them nationwide and internationally. The name itself is inspired by the work of Comenius Porta et Linguarum Trilinguis Reserata Aperta. Already in the seventeenth century, this distinguished author, Comenius emphasized two important aspects in the study of language teaching: first, its practicality and secondly, as a vehicle for communicative interplay between people of different nationalities.

The editorial board and the scientific committee are composed of relevant academic authorities of this area of study. Among others, personalities of national universities such as Santiago de Compostela, Malaga, Cordoba, Valladolid, Complutense de Madrid, Almeria, Las Palmas, Barcelona, Murcia, Granada, Ceuta and Melilla, along with different research groups. Internationally, among others, the universities of: Manchester, Macedonia, WisconsinMadison, Netherlands, Bogota, Mexico, Britain, Athens, France, Finland, Canada, Hungary, Denmark, etc.

\section{Method}

\subsection{Objectives of the study}

The main purpose of this work is the implementation of a bibliometric study on indicators of methodological quality for the magazine Porta Linguarum during the sexennial period 2008-2013. Based on this, to establish the strengths vs. weaknesses of methodological empirical nature present in the articles published in the magazine for its reinforcement (in the case of strengths) or, conversely, its improvement (in the case of weakness). 


\subsection{Design and procedures}

This research may be incardinated into the methodology known as descriptive. More precisely with Bisquerra (2004), Buendía, Colas \& Hernández (2012), Cohen, Manion \& Morrison (2010) and McMillan \& Schumacher (2005) can be considered as an analytical study. Analytical studies are characterized by methodological approaches in-depth study of printed documents through strategies of qualitative data analysis, such as content analysis.

\subsection{Sample}

As object of evaluation we have taken certain units of analysis. In our case, all articles are published in the journal Porta Linguarum during the sexennial period 2008-2013, i.e. a sample of $\mathrm{N}=161$. Therefore, there is no sensu strictu sampling process. Every article published in the journal, during the period noted, has been taken as an object of analysis regardless its empirical or theoretical nature.

\subsection{Bibliometric indicators of methodological character for scientific publcations used in this study}

Methodological standard indicators: These methodological elements per se does not facilitate or, on the contrary, promote varying methodological quality of a journal. They only report on methodological guidelines that dominate the journal and have, therefore, a more or less aseptic sense. In our case we have seen:

a) Methods of approaching the printed article published: experimental, quasi-experimental, causal-comparative, descriptive (survey study), correlational ... Frequencies and percentages of presence.

b) Methodologies of approaching the article published: experimental, ex post facto, qualitative, socio-critic. Frequencies and percentages of presence.

c) Data collection instruments used in the published article: Questionnaire, interview, measurement scales (Likert ...), standardized test, group discussion, ... Frequencies and percentages of presence.

Methodological quality indicators: These methodological elements whose presence or absence itself promotes greater or lesser methodological quality of the studies published in the journal. We understand as methodological quality indicators the followings:

a) Explanation or not of the sample size used in the research. Frequencies and percentages of presence or absence.

b) Explanation or not of the features that characterize the selected sample in the research. Frequencies and percentages of presence or absence.

c) Explanation or not of the type of sampling used in the research. Frequencies and percentages of presence or absence.

d) Explanation or not of the quality criteria (reliability, validity ...) of the measuring instruments used in the research. Frequencies and percentages of presence or absence. 
e) Typology of the data analysis techniques implemented in the research work. Frequencies and percentages of different analysis techniques used.

f) Software used in the data analysis implemented in the published article: SPSS, Statistica, BMDP, SAS, Statgraphics, N-Vivo, ATLAS-ti ... Frequencies and percentages of presence.

g) Bibliographic indicators

g1. Newness of the references used, based on the year of publication. To this end, we will use the arithmetic average of the years of the references in the first place, and the trimmed mean is used in extreme cases (outliers) that discourage its use by skewing the averages calculated. They also calculated the years distant from the base publication year and the trimmed mean of the references of articles published in that year.

g2. Degree of internationality of the references used in the work by calculating the internationality quotient of the references. This coefficient will be calculated as follows: CIB $=$ number of non-Spanish references / total number of references used in the paper.

g3. Average number of references used in each paper.

h) degree of internationality of the authorship of the works published by calculating frequencies and percentages of origin countries and the coefficients of international and local authorship as well as the language coefficient authorship. They are calculated as follows:

i1. $\mathrm{CAL}=$ number of non-Spanish authors who sign first/ total number of authors who sign first. This coefficient is operationalized into two $p+q=1$. In this case, if we turn them into percentage we have:

i.1.1. Percentage of national authorship.

i.1.2. Porcentage of international authorship.

i2. $\mathrm{CLA}=$ number of authors from the University of Granada signing first / total number of authors who sign first. This coefficient is also operationalized into two proportions $\mathrm{p}+\mathrm{q}=1$ that transformed into percentages are:

i2.1. Percentage of national / local authorship.

i2.1. Porcentage of external authorship.

i.3. CIA: number of articles published in Spanish / total number of published articles. This coefficient is operationalized into two proportions $p+q=1$ that converted into percentages are:

i.3.1.Porcentage of Spanish authorship.

i.3.2.Porcentage of authorship in another language besides Spanish.

\section{ANALysis AND Discussion OF Data}

For the analysis of the information collected we used the SPSS program versión.22. Through this analysis we have carried out different analysis of descriptive nature in line with the research objectives stated. Moreover, we present the results obtained around two groups of methodological indicators already referred to above. First, the group called standard indicators and, second, indicators of methodological quality. 


\subsection{Methodological standard indicators}

\subsubsection{Methods of approaching papers published and methodologies of approaching papers published}

For both, methods and methodologies of approach, firstly we have to highlight the significant presence of strictly theoretical papers. These are 60 of the 161 evaluated, representing $37.3 \%$ of the total, more than $1 / 3$. Since our focus is on purely methodological aspects, such works have been overlooked. We can affirm, in any case, the journal Porta Linguarum has a considerable percentage of theoretical papers that characterize it as a less empirical journal compared to others, but it does not undermine its solvency at all as a quality journal.

Focusing on empirical papers we appreciate the predominance of ex post facto methodologies (37.2\%) and within descriptive methods (survey study) with $26.7 \%$ of the cases evaluated and, in a lesser extent, the correlational $(5 \%)$, causal comparative $(2.5 \%)$, analytic studies (1.9\%) and finally the performance studies (1.2\%). Thirdly, experimental methodologies $(15.5 \%)$ and within those using quasi experimental designs (9.9\%) and strictly experimental (5.6\%). Fourth, we locate qualitative methodologies $(6.8 \%)$ and within it case studies $(5 \%)$ and the ethnographic method (1.9\%). Finally, there are articles that have used another type of method and methodology (3\%) and a socio critic methodology (specifically action research) and methodological essays $0.6 \%$ of the cases respectively.

\subsubsection{Data collection instruments used in the published papers}

Since there have been obviated theoretical papers, we have only considered empirical ones, in our case $\mathrm{N}=101$. The results achieved in this regard are as follows.

As it can be seen, quantitative instruments are the ones with a greater presence. So, questionnaires are the data collection technique most commonly used in the empirical studies published in the journal, exactly the $56.43 \%$ of them (more than half of the assessed papers). Moreover, these instruments have been used, also representing $31.8 \%$ if we consider the other data collection tools. Secondly, we have other techniques for gathering information $(22.7 \%)$ representing $12.8 \%$ of the rest of the instruments. In this group we have found, above all, the use of online channels (chat rooms, forums ...) to collect the information. Third, we find standardized tests. These strategies have been used in $21.78 \%$ of the items assessed representing $12.3 \%$ compared to the instruments for collecting information. Fourth, measurement scales, especially those concerning Likert format. $18.81 \%$ of the published articles have used this strategy representing $10.6 \%$ of the instruments for collecting information. Fifth, here we have the surveys. $15.84 \%$ of the published articles have used these strategies for data collection, representing $8.9 \%$ of all instruments. Closely we found the observation and documents. In both cases, it was found that $14.85 \%$ and $10.89 \%$ of the articles used such strategies respectively to collect information, representing $8.4 \%$ and $6.1 \%$ over the rest of information collection tools.

Other more qualitative techniques for collecting information, such as narrative stories (6.93\% and $3.9 \%$ compared to the other techniques), images (3.96\% and $2.2 \%$ compared to the other techniques), discussion groups (2.97\% and $1.7 \%$ compared to the other techniques), life stories $(0.99 \%$ and $0.6 \%$ compared to other techniques), have achieved much less incidence. 


\subsection{Methodological quality indicators}

\subsubsection{Type of sampling of published papers}

Regarding the type of sampling of the papers published it has been confirmed that $35.64 \%$ of articles published are strictly empirical, exactly 36 out of 101 . In these papers there is no reference at all to the type of sample used in the research carried out. On the other hand those papers where the type of sample used is explicit, $51.49 \%$ of them reported to have used non-probability based sampling, while only $7.92 \%$ of cases reported the presence of simple random probability based samples; $4.95 \%$ used strictly qualitative sampling. The massive use of non-probability sampling does not undermine the conclusions that may have been obtained in the papers published and that have used this sampling strategy. However, it complicates the possibility to spread the findings to other contexts in a high degree (external validity) and this can become a serious methodological problem, if we consider the large presence of experimental and ex post facto, papers whose logic is ruled by the sample to population.

A more important issue is the presence of more than one third of empirical articles, exactly $35.64 \%$, where the authors have not made explicit the type of sampling used. In order to a better future understanding of empirical papers published it is essential to know in detail the methodological procedure implemented. A key element in this process is to present and justify the choice of sampling used, besides the size and sample characteristics that we will address in detail below.

\subsubsection{Shows or not the sample size used and the characteristics of the sample}

Unlike earlier, indicators on sample size and sample characteristics have actually obtained satisfactory results. In this sense, we can see, as $92.08 \%$ (93 out of 101) of the empirical articles evaluated refer to the sample size used. Also important is the percentage of empirical studies that have explained the main sampling features that characterize the samples used, exactly $89.11 \%$ (90 out of 101 ).

\subsubsection{Shows or not the quality criteria of data collection instruments}

As for the quality criteria of measuring instruments, we have seen that $70.30 \%$ (71 of 101) of the empirical studies evaluated did not make explicit or implicit reference to those parameters. $14.85 \%$ does include aspects of reliability and validity, while $10.9 \%$ only explains aspects of reliability and only a $2.97 \%$, of validity a $0.99 \%$ of the articles ( 1 out of 12 with a qualitative or socio-critic character) has mentioned qualitative quality criteria. The results achieved in this methodological indicator of quality are not very encouraging. It is important, therefore, to improve outcomes in this indicator. The editorial staff and evaluators must require the explanation and justification of the quality criteria of the data collection instruments used.

\subsubsection{Software used and data analysis procedures developed}

About the software used, the majority the (71.29\%) of the papers published does not refer to the data analysis program used in the data analysis implemented either quantitative 
or qualitative. On the contrary when the type of program used is specified it can be appreciated that SPSS $(20.79 \%)$ is the most commonly used. Far from it we can find other data analysis programs such as BMDP and AMOS with a symbolic $0.99 \%$ respectively. Using several instruments at a time in the same research work and other kinds of software not included in the reference question amounted to $2.97 \%$ respectively.

Regarding the quantitative and qualitative analysis techniques used we can see how the use of descriptive statistics have reached a higher incidence. Thus $84.15 \%$ ( 85 of 101 of empirical nature) of the papers analyzed used descriptive statistics (average, standards deviations...). We also point out that, if we consider the analysis strategies used, 42.9\% corresponds to this type of analysis strategies. Second, 39.6\%t of he studies analyzed (40 of 101) used parametric significance tests (T tests, ANOVA, ANCOVA ...). Regarding analysis procedures they represented $20.2 \%$ of the total. Third, the papers evaluated have referred to the use of correlations (Pearson product moment, Spearman ...), exactly $28.71 \%$ of the cases (29 of 101) as well as $14.6 \%$ of the procedures developed. Fourth, we find the development of procedures for qualitative analysis (reduction, coding and categorization ...) of nonnumerical information collected (13.86\%) which represents 14 out of 101 items evaluated. In relation to the type of analysis techniques, methods of qualitative analysis represent $7.1 \%$ of them. With much lower incidence rates we found other data analysis techniques, such as significance tests for nonparametric type (U-Mann Whitney, Wilcoxon ...) with $8.91 \%$ (9 of 101) as well as other strategies of multivariable nature, among which exploratory and confirmatory factor analysis (3.96\%) and with a lower incidence multiple linear regression, correspondence analysis ...

Finally, we found that $4.95 \%$ of the evaluated items used content analysis and other data analysis techniques such as multilevel tests, technical CHAID...

\subsubsection{Reference indicators}

Table 1. Descriptive data related to reference indicators of the papers published during the sexennial period 2008-2013 in the journal Porta Linguarum

\begin{tabular}{|c|c|c|c|c|c|c|c|}
\hline $\begin{array}{c}\text { Year of } \\
\text { publication }\end{array}$ & $\begin{array}{c}\text { References } \\
\text { indicators } \\
\text { considered }\end{array}$ & $\mathbf{N}$ & Min. & Max. & Mean & $\begin{array}{c}\text { Trimmed } \\
\text { mean 5\% } \\
\text { between } \\
\text { base year of } \\
\text { publication } \\
\text { and trimmed } \\
\text { mean of the } \\
\text { references }\end{array}$ \\
\hline YEAR 2008 & $\begin{array}{c}\text { Mean years- } \\
\text { literature }\end{array}$ & 26 & 1946 & 2003 & 1993,92 & 1995,55 & 13 years \\
\cline { 2 - 8 } & $\begin{array}{c}\text { Number of } \\
\text { references }\end{array}$ & 26 & 6 & 51 & 24,42 & 24,51 & - \\
\cline { 2 - 8 } & $\begin{array}{c}\text { Coefficient of } \\
\text { internationality }\end{array}$ & 26 &, 13 & 1 &, 78 &, 80 & - \\
\hline
\end{tabular}




\begin{tabular}{|c|c|c|c|c|c|c|c|}
\hline \multirow{3}{*}{ YEAR 2009} & $\begin{array}{c}\text { Mean years- } \\
\text { literature }\end{array}$ & 24 & 1860 & 2003 & 1990,62 & 1996,01 & 13 years \\
\hline & $\begin{array}{l}\text { Number of } \\
\text { references }\end{array}$ & 24 & 7 & 64 & 27,46 & 28,21 & - \\
\hline & $\begin{array}{l}\text { Coefficient of } \\
\text { internationality }\end{array}$ & 24 & 0 & 1 &, 83 & ,86 & - \\
\hline \multirow{3}{*}{ YEAR 2010} & $\begin{array}{c}\text { Mean years- } \\
\text { literature }\end{array}$ & 23 & 1987 & 2004 & 1995,92 & 1995,98 & 15 years \\
\hline & $\begin{array}{l}\text { Number of } \\
\text { references }\end{array}$ & 23 & 11 & 88 & 29,39 & 29,49 & - \\
\hline & $\begin{array}{l}\text { Coefficient of } \\
\text { internationality }\end{array}$ & 23 & ,20 & 1 & ,79 &, 81 & - \\
\hline \multirow{3}{*}{ YEAR 2011} & $\begin{array}{l}\text { Mean years- } \\
\text { literature }\end{array}$ & 26 & 1930 & 2003 & 1991,73 & 1994,01 & 17 years \\
\hline & $\begin{array}{l}\text { Number of } \\
\text { references }\end{array}$ & 26 & 10 & 74 & 33,27 & 33,89 & - \\
\hline & $\begin{array}{l}\text { Coefficient of } \\
\text { internationality }\end{array}$ & 26 & ,20 & 1 & ,87 & ,90 & \\
\hline \multirow{3}{*}{ YEAR 2012} & $\begin{array}{c}\text { Mean years- } \\
\text { literature }\end{array}$ & 26 & 1946 & 2007 & 1996,53 & 1998,22 & 14 years \\
\hline & $\begin{array}{l}\text { Number of } \\
\text { references }\end{array}$ & 26 & 9 & 61 & 36,38 & 36,89 & - \\
\hline & $\begin{array}{l}\text { Coefficient of } \\
\text { internationality }\end{array}$ & 26 &, 14 & 1 &, 77 &, 80 & - \\
\hline \multirow{3}{*}{ YEAR 2013} & $\begin{array}{l}\text { Mean years- } \\
\text { literature }\end{array}$ & 36 & 1991 & 2009 & 2001,11 & 2001,18 & 12 years \\
\hline & $\begin{array}{l}\text { Number of } \\
\text { references }\end{array}$ & 36 & 8 & 60 & 27,50 & 27,01 & - \\
\hline & $\begin{array}{l}\text { Coefficient of } \\
\text { internationality }\end{array}$ & 36 &, 08 & 1 &, 78 &, 81 & - \\
\hline
\end{tabular}

Regarding the reference indicators considered we have analiysed, first, the indicator referred to new or, conversely, old references used in the 161 items tested (theoretical + empirical), if we take as baseline the year of publication. For this purpose we have calculated the arithmetic mean and, complementary, the trimmed mean when, as it has been the case of a few years, there have been very old references (extreme or outlier values), generating 
a situation that Tukey (1977) called disorder (rough). Therefore, we took as a reference the trimmed mean $5 \%$ in all cases.

Given this premise, we can see how, overall in the 6 years evaluated, the distance between the base years used as reference and the trimmed mean from the literature used each year in the articles is around 14 years old (exactly 13,66). Thus, we find years with greater distances and therefore greater antiquity of their literature in 2010 (15 years) and 2011 (17 years) and shorter distances in the years 2008 and 2009 (13 years) and 2013 (12 years ). In a middle term lies the year 2012 (14 years). The following chart shows in detail the differences between the base years used as reference and the trimmed means of the literature used in articles by year of publication.

Graphic 1. Differences between the base years of publication and references trimmed means used in each year of the articles published in the journal Porta Linguarum during the sexennial period from 2008 to 2013.

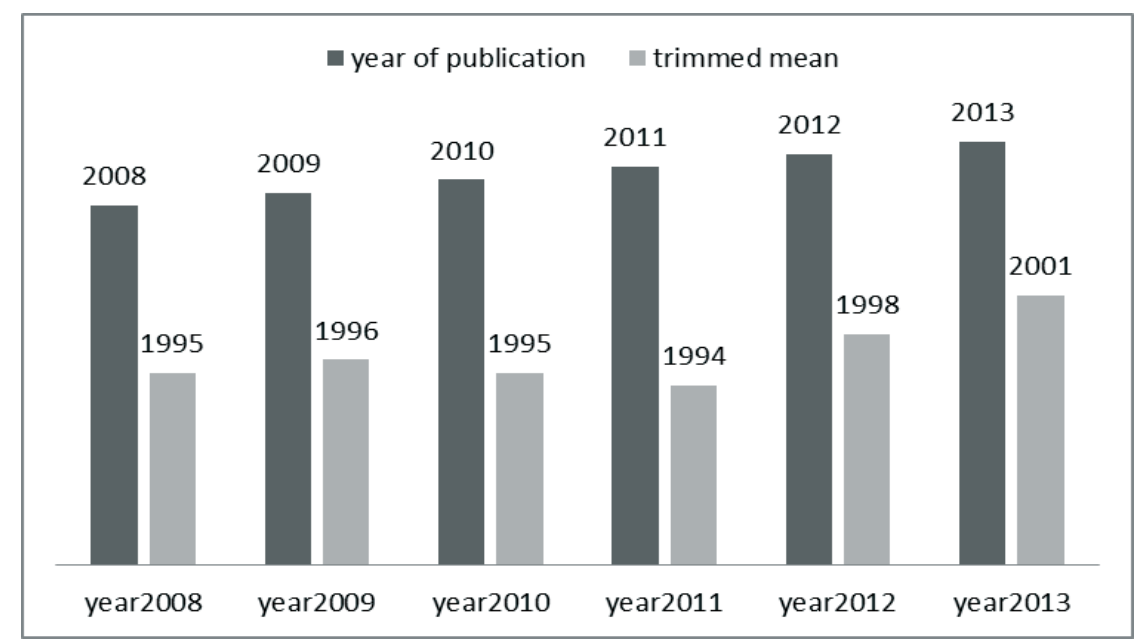

It can be clearly seen, how in the years 2010 and 2011, the line corresponding to the trimmed means of the literature used in the articles published those years, was heeling over to the left, i.e. towards the vertical axis indicating that references were older, in relation to the year of publication. On the contrary in 2012 and 2013 line path of the trimmed mean is heeling to the right, denoting a lower age of the references.

Another aspect analyzed about reference indicators is the number of references per article. As we have previously determined there is an increasing trend in the number of references used in the papers evaluated from 2008-2012 with an overall average of 29.67 citations per article. Thus, we can see how the lower average was obtained in 2008, with an average of 24.42 publications, as far as it has been consolidated in 2012 with nearly 37 references per article. In 2013 there has been a sharp fall 27.5 citations per article.

Finally, in relation to the reference section, we present results on the internationality coefficient of reference used. 
Graphic 2. Representation of the percentages of Spanish vs non Spanish references used in the articles published in the journal Porta Linguarum during the sexennial period from 2008 to 2013.

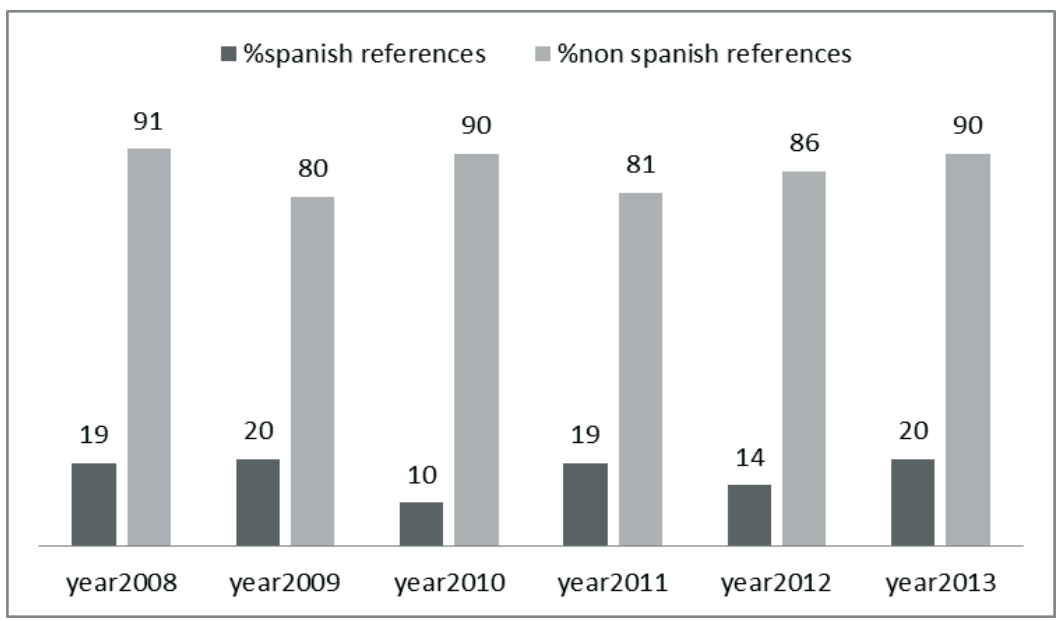

In view of the heightened international character distinguishing the journal Porta Linguarum, as we will discuss in the following paragraph, there is no wonder they have achieved high percentages of non-Spanish references during the sexennial period evaluated. The coefficient of internationality of the literature has risen $(0.83)$ on average, i.e. $83 \%$ of the references in the articles reviewed are not from Spain, while the remaining $17 \%$ are from Spain. If analyse it per years, it stands out above all, the year 2011 with a coefficient of 0.90 . Anyway, in any of the years evaluated the coefficient drops from 0.80 which shows the high degree of internationality of the journal.

Finally, we evaluated the indicator internationality of the journal, taking into account different indicators.

\subsubsection{Degree of authorship internationality}

For reasons of space, we don't show descriptive results obtained at the level of the first author representation by order of signature and by universities, countries and continents. However, we can conclude there is a significant degree of internationality that characterizes this journal Porta Linguarum. Notwithstanding the most interesting fact in this section has been calculating the coefficients Local Authorship; The International Authorship; and Authorship Language that transformed into percentages, for a better understanding, are presented in three areas graphs, differentiating by year of publication. 


\subsection{Coefficient of local authorship}

Graphic 3. Representation of internal authorship percentages (University of Granada) and external authorship (other universities) of the journal Porta Linguarum during the sexennial period 2008-13.

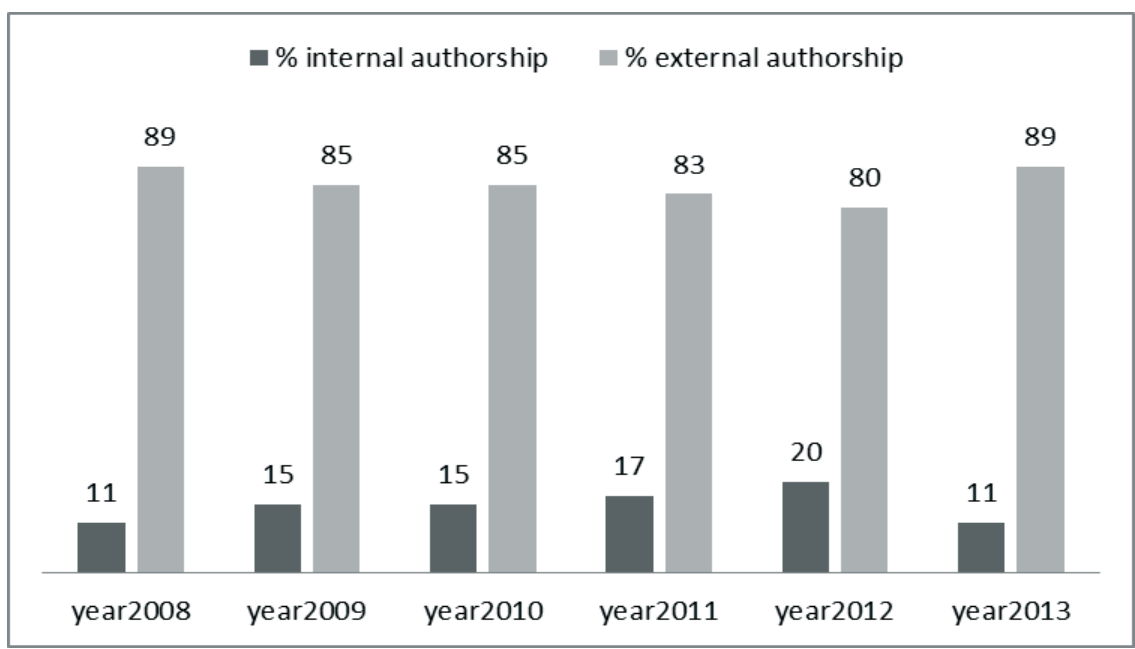

As shown in the preceding figure, the coefficient of local ownership in the sexenial period 2008-2013 reaches an average of 0.15 , or what is the same, an internal authorship of the University of Granada of $15 \%$ compared to $85 \%$ of external authorship- from outside the University of Granada. It is also interesting to note that the first and last years of the series taken into consideration (2008 and 2013), have achieved the highest percentages of foreign authorship, almost $90 \%$ of the published articles belong to authors from outside the University of Granada. These data reveal the high degree of inbreeding control by authorship practiced in the journal, since the maximum tolerable percentages established by FECYT and CNEAI are $20 \%$ and $25 \%$ respectively. In no case, except for the year 2009 , of the years evaluated tolerable limits of inbreeding by authorship have been exceeded. On the contrary they are 5 and 10 percentage points below the limit. 


\subsection{Coefficient of authorship language}

Graphic 4. Representation of the percentages of national vs. international authorship of the journal Porta Linguarum during the sexennial period 2008-13.

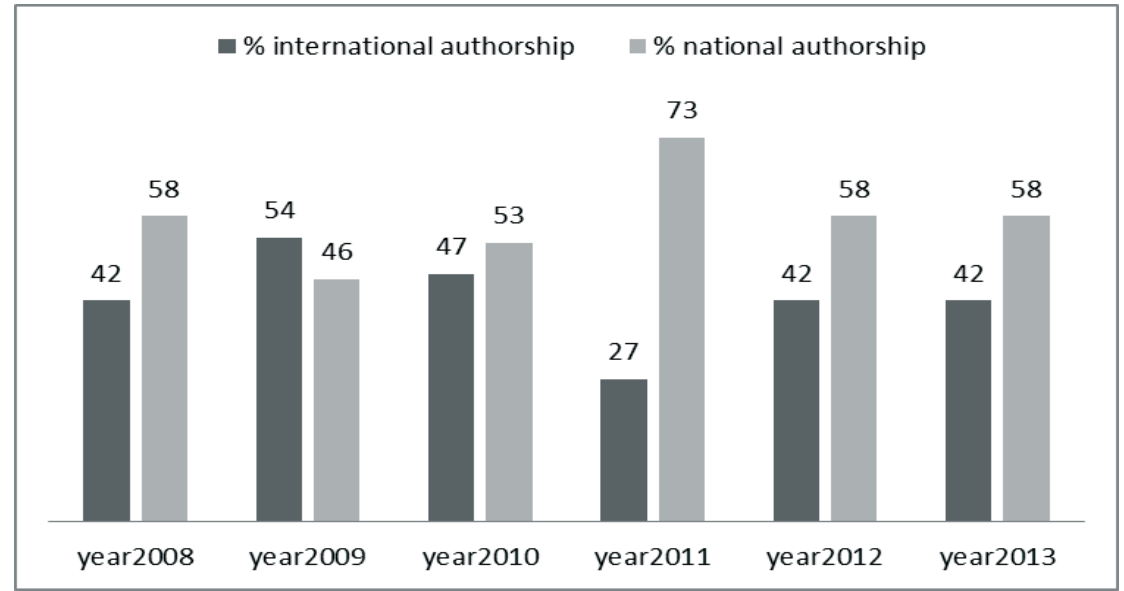

In the indicator related to the internationality of authorship, data obtained point out a greater number of national articles published. On average, the coefficient of internationality of authorship is 0.42 , compared to the remaining 0.58 that would correspond to national ownership. In this context, we found that over half of the articles published (58\%) during the sexennial period 2008-2013 in the journal Porta Linguarum are of national authorship compared to $42 \%$ that is of international authorship. We emphasize the fact that during 2012 the number of articles of international authorship was higher (54\%) than those of national authorship (46\%). Anyway, journal Porta Linguarum has a significant percentage of international authorship. It would be interesting to contrast this fact with the rest of publications in the field of educational research in general. 


\subsection{Coefficient of international authorship}

Graphic 5. Representation of authorship percentages in Spanish language vs non Spanish language in journal Porta Linguarum during the sexennial period 2008-13.

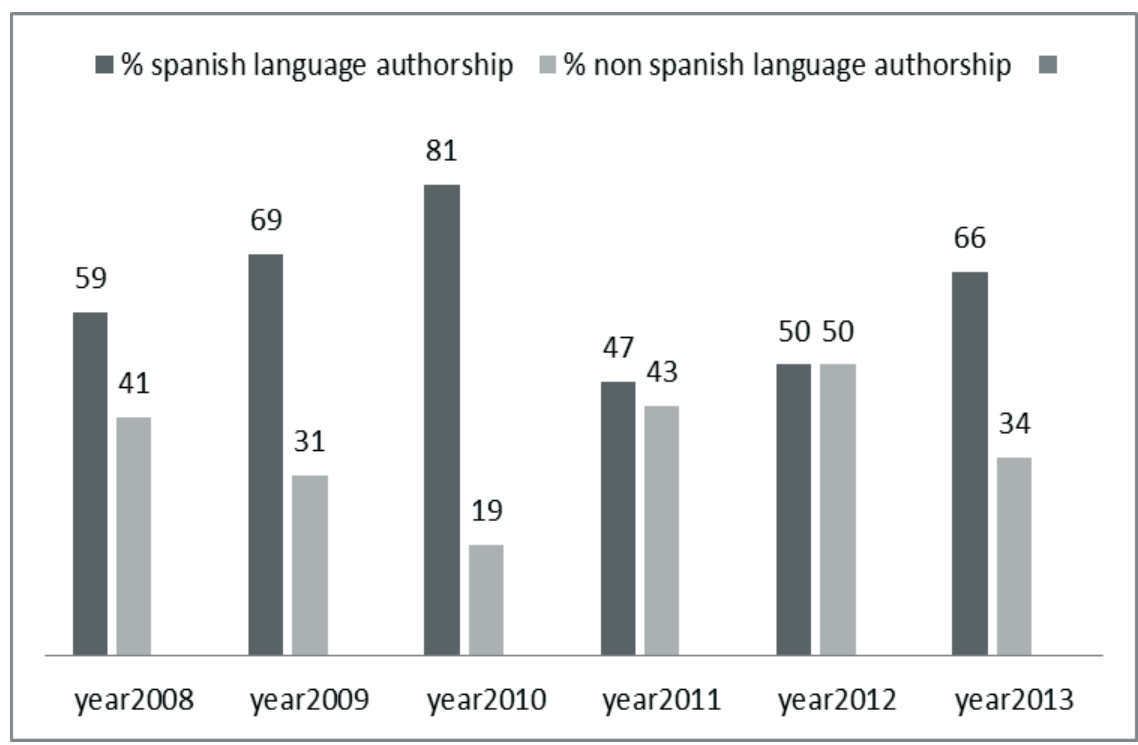

Finally, in relation to the language used in the evaluated papers we can appreciate (on average) how the coefficient of authorship language has reached the value of 0.60 . This means that $60 \%$ of the articles published in the journal Porta Lingurum are written in a non-Spanish language, compared to $40 \%$ that are in Spanish language. In the analysis of the years of publication, we have to highlight, especially 2011 when the authorship in non Spanish language reached of 0.81 , i.e. $81 \%$ of the papers published that year were not written in Spanish.

\section{Conclusions AND SUgGestions FOR IMPROVEMENT}

As it is known, the excellence of scientific journals in the current scenario is measured by calculating certain indicators that have little or nothing to do with the methodological quality of the papers published on it. An interesting example of such dysfunction is described with great success by Buela-Casal (2003). It is worth the quiet reading of this work to try to understand that the quality of a publication cannot and should not be based solely on visibility and citation indicators. So, the well known impact factors are the ones that denote the varying quality of a publication. Currently, both the JCR impact factors (Journal Citation Report) ISI, and the SJR (SCImago Journal Rank) SCOPUS, or the h-index (Hirsch, $2005,2007)$ provide the relevance of a publication in a specialized field determined from 
the citations received. However, this work has focused on trying to determine the methodological quality of the scientific production of the journal analyzed, in our case, Porta Lingurum, rather than focusing on the visibility and citation of their papers. It is clear that the quality of an article published in a scientific journal is based on the content on it. So the development of the theoretical framework (theoretical works), is as important as the methodological framework and analytical conclusions (in the case of empirical works) in each paper. Unfortunately, the indicators shown in this work are still merely approximate, since they do not go into detail in the "real" methodological quality of published works, which is an arduous and complex task. However, these indicators seem useful as an evaluation strategy to determine the lower or higher methodological quality of the studies published in a journal. In relation to the journal evaluated, we have come to the following conclusions and suggestions for improvement:

In relation to the methodology indicators: Journal Porta Linguarum presents a significant percentage of theoretical papers $(37.4 \%)$. The recent research work of Níkleva and Cortina (2014), about an evaluation conducted of two journals in the field of teaching foreign languages, along with Porta Lingurum also reflects similar results, although obviously not exactly the same, taking into account that their study has taken into consideration the series 2009-2011. Moreover, it is also a proven fact the important presence of quantitative papers, $(52.7 \%)$ of them, if we add experimental, and ex post facto papers, in contrast to the qualitative and socio-critical only reaching $7.4 \%$ of the total assessed. In the research conducted by Níkleva and Cortina (2014), papers of quantitative, qualitative and socio-critical nature have obtained lower presence percentage. Obviously, the reason is, as highlighted above, the number of years specified in each paper, and certainly in the taxonomy of methods used in each study. About the strategies for collecting information, according to the researched methods used, there is a predominance of quantitative techniques (questionnaires, scales of measurement ...) with almost $55 \%$ compared to approximately $33 \%$ of qualitative instruments (interviews, discussion groups ...), since the presence of otherinformation collection techniqued is estimated at around $13 \%$ (forums, chats ...).

With regard to methodological quality indicators: first, about the process of sampling and type of publication, we have obtained contradictory results. First, the issue of size and features that characterize the sample have obtained excellent and satisfactory results, however, it has occurred the opposite in the explanation of the type of sampling. More than $1 / 3$ of the empirical reviewed articles do not mention the type of sample used, dominating in all cases papers where non-probability sampling were used, which is legitimate, though inconsistent given the massive presence of quantitative papers. Neither are good the results on quality criteria for measuring instruments. Over $70 \%$ of the empirical articles obviate the quality criteria either from the quantitative positioning of classical test theory or rival theories (reliability and validity) as well as qualitative (confirmability, dependency ...). Another neglected aspect is the lack of explanation of the computer software used in the analysis of the collected information; almost $72 \%$ of the empirical articles obviate its explanation and when they do it, we see the predominance of the SPSS program. Closely related to the latter, we also underline the predominance of descriptive analysis and somewhat in less proportion those of inferential nature. The use of multivariable analysis with qualitative analysis procedures is really low. These indicators should be taken into consideration by the editorial staff and evaluators of the journal in order to improve their methodological indicators, not so much 
with regard to technical analysis but to other aspects related to the processes of sampling and quality criteria for data collection instruments.

With regard to biographic indicators, we have also obtained contradictory results. First, as for the presence of updated literature used in the papers in relation to the year of publication, we found empirical evidence that the literature is around 13 years old. Therefore, it is also an aspect to improve by the editorial staff and evaluators to require a more updated literature in the papers accepted for publication. However, regarding the internationality of the literature used, it was calculated using the coefficient of internationality of literature (CIB) and we have found $80 \%$ average of non-Spanish references. This reveals the international nature of the publication. Moreover, to reinforce this conclusion we can say that $60 \%$ average of the papers are written in a language different from Spanish with the participation of $42 \%$ of foreign authors. Finally, Journal Porta Liguarum has been very successful in controlling inbreeding authorship, another very important aspect. In this sense, this publication has obtained 15\% average of local authorship (authors from the University of Granada) lower at any rate; the maximum required from the FECYT and CNEAI is $20 \%$ and $25 \%$ respectively.

\section{REFERENCES}

Arnau, J., Anguera, M.T. y Gómez, J. (1990). Metodología de las ciencias del comportamiento. Murcia: Universidad de Murcia.

Bisquerra, R. (2004). Metodología de la investigación educativa. Madrid: La Muralla.

Buela, G. (2010). "Scientific jounal impact indexes and indicators for measuring researcher performance", en Revista de Psicodidáctica , 5(1): 3-19.

Buela-Casal, G. y Zych, I. (2010). "Analysis of the relationship between the number of citations and the quality evaluated by exprets in psychology journals", en Revista Psicothema, 22: 270-76.

Buela-Casal, G., Bermúdez, M.P., Sierra, J. C., Quevedo-Blasco, R. y Castro, A. (2010). "Ranking de 2009 en investigación de las universidades públicas españolas", en Revista Psicothema, 22, 924-31.

Buendía, L. y Colás, P. y Hernández, F. (2012) (4aed.). Métodos de Investigación en Psicopedagogía. Madrid: Mc Graw-Hill.

Carpallo-Bautista y Burgos-Bordonau, E. (2008). "Estudio bibliométrico y de calidad de la revista Complutense de Educación (1990-2007)", en Revista Complutense de Educación, 1: 13-29.

Cohen, L., Manion, L. \& Morrison K. (2010). (7 $7^{a}$ edición). Research methods in education. Oxan: Routlegde.

Delgado López-Cózar, E., Ruiz Pérez, R. y Jiménez Contreras, E. (2010). “Qué es y cómo utilizar el índice de Impacto de Revistas Españolas de Ciencias Jurídicas”, en Revista Aula Abierta, 38: 3-16.

Flórez Parra, J.M., López Pérez, M. V. y López Hernández, A.M. (2014). “Gobierno corporativo y sector público: un estudio bibliométrico en las principales revistas ISI", en Innovar: revista de ciencias Administrativas y Sociales, vol. 24, $\mathrm{n}^{\circ}$ 51: 79-98. 
Giménez Toledo, E. (2014). "Imposturas en el ecosistema de la producción científica", en Revista de Investigación Educativa, v. 32, $\mathrm{n}^{\circ}$ 1:13-23.

Gómez-García, M. Ramiro, M. T. Ariza, T. y Reina-Granados, M. (2012). "Estudio bibliométrico de Educación XX1", en Revista Educación XXi, $n^{\circ}$ 15.1: 17-41.

Goñi, A. (2009). "La Revista de Psicodidáctica en el Social Sciences Citation Index", en Revista Psicodidáctica, 14 (1): 7-12.

Mc Millan, J. \& Schumacher, S. (2005). Investigación educativa. Madrid: Pearson Educación.

Madrid. D. (2004). "Introducción”, en Porta linguarum, $\mathrm{n}^{\circ}$ 2: 5-9.

Mintegi, L. Esnaola, I. Díaz y Goñi, A. (2011). "Los quince años (1996-2010) de la revista Psicodidáctica”, en Revista Psicodidáctica, n¹6(1):3-17.

Níkleva, G.D. y Cortina, B. (2014). "La producción científica actual en Didáctica de la Lengua y la Literatura en revistas españolas", en Porta Linguarum, n $^{\circ}$ 21: 281-299.

Olivas Avila, J. A y Musi Lechuga, B. (2014). "Validez y fiabilidad del Researcher ID y de Web of Science Production of Spanish Psychology", en International Journal of Clinical and Health Psychology, vol. 14, nº1: 58-66.

Tukey, J. W. (1977). Exploratory Data Analysis. Reading: Addison-Wesley.

Quevedo-Blasco, R. Díaz-Piedra, C. y Guglielmi, O. (2010). "Análisis comparativo de las publicaciones sobre drogodependencias en las revistas de Psicología Clínica y Psiquiatría iberoamericanas indexadas en el Jounal Citation Reports", en Revista Salud Mental, 33: 133-143.

Zych, I. (2011). “Estudio bibliométrico de la revista Bordón”, en Revista Bordón, 63(2): 141-152. 